\title{
Impurity gettering effect of atomic layer deposited aluminium oxide films on silicon wafers
}

A. Y. Liu and D. Macdonald

Citation: Appl. Phys. Lett. 110, 191604 (2017); doi: 10.1063/1.4983380

View online: http://dx.doi.org/10.1063/1.4983380

View Table of Contents: http://aip.scitation.org/toc/apl/110/19

Published by the American Institute of Physics

\section{Articles you may be interested in}

Effects of device size and material on the bending performance of resistive-switching memory devices fabricated on flexible substrates

Applied Physics Letters 110, 192103 (2017); 10.1063/1.4983383

High reverse breakdown voltage Schottky rectifiers without edge termination on $\mathrm{Ga}_{2} \mathrm{O}_{3}$

Applied Physics Letters 110, 192101 (2017); 10.1063/1.4983203

High temperature operation of $\mathrm{n}-\mathrm{AlGaN}$ channel metal semiconductor field effect transistors on low-defect AIN templates

Applied Physics Letters 110, 193501 (2017); 10.1063/1.4982656

Control of work function of $\mathrm{MoS}_{2}$ with ferroelectric polarization in honeycomb-like heterostructure

Applied Physics Letters 110, 191601 (2017); 10.1063/1.4983204

Epitaxial growth and band alignment properties of $\mathrm{NiO} / \mathrm{GaN}$ heterojunction for light emitting diode applications Applied Physics Letters 110, 191603 (2017); 10.1063/1.4983200

Cold exciton electroluminescence from air-suspended carbon nanotube split-gate devices

Applied Physics Letters 110, 191101 (2017); 10.1063/1.4983278

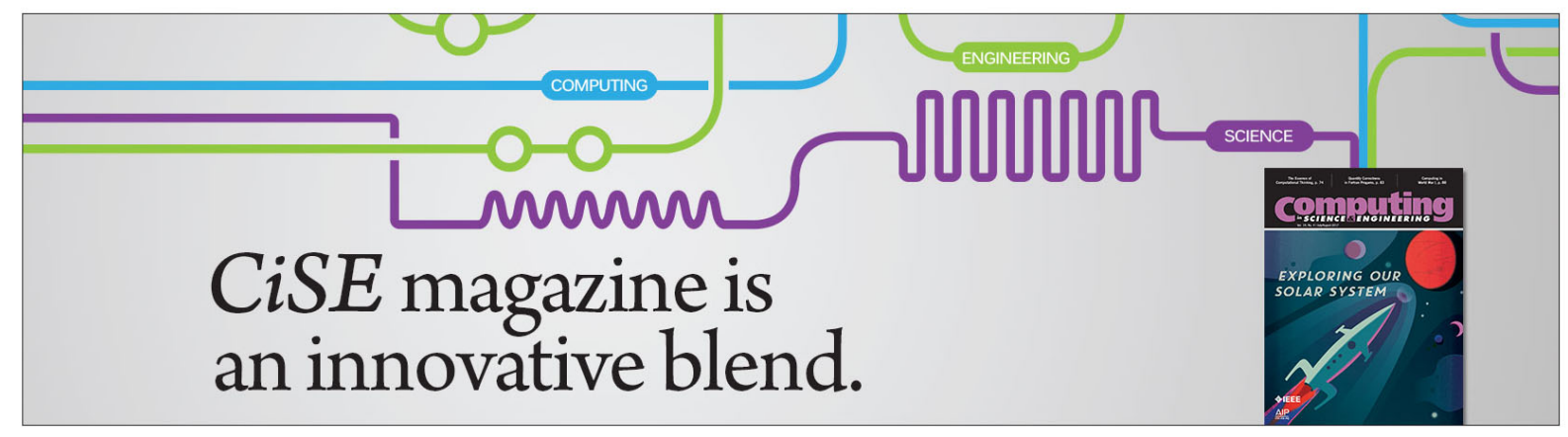




\title{
Impurity gettering effect of atomic layer deposited aluminium oxide films on silicon wafers
}

\author{
A. Y. Liu and D. Macdonald \\ Research School of Engineering, College of Engineering and Computer Science, \\ The Australian National University, Canberra, ACT 2601, Australia
}

(Received 23 February 2017; accepted 30 April 2017; published online 10 May 2017)

\begin{abstract}
We present experimental evidence for the impurity gettering effect of atomic layer deposited aluminium oxide $\left(\mathrm{Al}_{2} \mathrm{O}_{3}\right)$ films on silicon wafers, during typical surface passivation activation at $425^{\circ} \mathrm{C}$. Iron was used as a model impurity in silicon to study the gettering effects. Dissolved iron concentrations were determined by carrier lifetime measurements, allowing the iron loss kinetics in silicon wafers with $\mathrm{Al}_{2} \mathrm{O}_{3}$ coatings to be monitored during annealing. The redistribution of iron to the surface layers and the sub-surface regions was examined by secondary ion mass spectrometry depth profiling. The results show that the atomic layer deposited $\mathrm{Al}_{2} \mathrm{O}_{3}$ films generate a strong gettering effect, removing $50 \%$ of the iron after $30 \mathrm{~min}$ at $425^{\circ} \mathrm{C}$ for a $160-\mu \mathrm{m}$ thick silicon wafer. The iron reduction process is largely diffusion-limited in the initial stages. The gettering effect is caused by the accumulation of iron at the $\mathrm{Al}_{2} \mathrm{O}_{3} / \mathrm{Si}$ interface. Published by AIP Publishing .

[http://dx.doi.org/10.1063/1.4983380]
\end{abstract}

Atomic layer deposited (ALD) aluminium oxide $\left(\mathrm{Al}_{2} \mathrm{O}_{3}\right)$ films provide excellent passivation for both moderately doped $\mathrm{p}$ - and n-type silicon surfaces and for heavily doped p-type surfaces, owing to their high fixed negative charge density and low interface defect density. ${ }^{1-3}$ ALD $\mathrm{Al}_{2} \mathrm{O}_{3}$ films have therefore emerged as an important and widely adopted surface passivation technology in the past decade, ${ }^{4}$ used in both p- and n-type silicon solar cells (for example, as demonstrated in Refs. 5 and 6).

The interaction of the $\mathrm{ALD} \mathrm{Al}_{2} \mathrm{O}_{3}$ films with metallic impurities in the silicon bulk, however, remains unexplored. It was recently reported that plasma-enhanced chemical vapour deposited (PECVD) silicon nitride $\left(\mathrm{SiN}_{\mathrm{x}}\right)$ films possess a strong gettering effect for bulk impurities, via a segregation gettering mechanism. ${ }^{7}$ This was revealed by monitoring the redistribution of iron $(\mathrm{Fe})$ in the $\mathrm{SiN}_{\mathrm{x}}$ films and the silicon wafer bulk after annealing. ${ }^{7}$ Here, we aim to examine the possible gettering effect of $\mathrm{ALD} \mathrm{Al}_{2} \mathrm{O}_{3}$ films at a typical film activation temperature of $425^{\circ} \mathrm{C}$. $\mathrm{ALD} \mathrm{Al}_{2} \mathrm{O}_{3}$ films generally require a post-deposition anneal between 300 and $500^{\circ} \mathrm{C}$, for several minutes to tens of minutes, in order to activate the surface passivation effect. ${ }^{8}$ Iron is used as a model impurity to assess the gettering effect, as dissolved interstitial iron $\left(\mathrm{Fe}_{i}\right)$ in silicon can be easily and accurately quantified using lifetime based techniques. ${ }^{910}$ Moreover, iron is a common efficiencylimiting impurity in silicon solar cells. ${ }^{11}$ The gettering effect of the $\mathrm{ALD} \mathrm{Al}_{2} \mathrm{O}_{3}$ films at $425^{\circ} \mathrm{C}$ is examined by monitoring the $\mathrm{Fe}_{i}$ loss kinetics in the silicon wafer bulk via quasi-steadystate photoconductance (QSSPC) lifetime measurements and by assessing the redistribution of $\mathrm{Fe}$ in the $\mathrm{Al}_{2} \mathrm{O}_{3}$ films and the near-surface regions of the Si substrate via secondary ion mass spectrometry (SIMS) analysis.

The samples used in this work were boron-doped $p$-type float-zone (FZ) silicon wafers with known doses of intentional iron contamination, introduced by implanting the Si wafers with ${ }^{56} \mathrm{Fe}$ using a relatively low ion implantation energy of $70 \mathrm{keV}$. The implantation doses were $1.8 \times 10^{11} \mathrm{~cm}^{-2}$ and $1.8 \times 10^{12} \mathrm{~cm}^{-2}$ for the wafers with a resistivity of $0.9 \Omega \mathrm{cm}$ and a thickness of $180 \mu \mathrm{m}$ (after saw damage etching in an alkaline solution), which corresponded to volumetric $\mathrm{Fe}$ concentrations of $10^{13} \mathrm{~cm}^{-3}$ and $10^{14} \mathrm{~cm}^{-3}$, respectively. $270-\mu \mathrm{m}$ thick and $1.7 \Omega \mathrm{cm} p$-type FZ-Si wafers were also used, which were implanted with $8 \times 10^{10} \mathrm{~cm}^{-2} \mathrm{Fe}$ to result in a volumetric Fe concentration of $3 \times 10^{12} \mathrm{~cm}^{-3}$. After ion implantation, the wafers were annealed at $1000^{\circ} \mathrm{C}$ to uniformly distribute the implanted $\mathrm{Fe}$ throughout the wafer thickness. The implantation energy and doses used here, combined with a $1000^{\circ} \mathrm{C}$ post-implantation anneal, are expected to result in negligible residual damage in silicon wafers. ${ }^{12}$

At $1000^{\circ} \mathrm{C}$, the Fe solubility in $\mathrm{Si}$ is $4 \times 10^{14} \mathrm{~cm}^{-3},{ }^{13}$ above the targeted $\mathrm{Fe}$ concentrations of $3 \times 10^{12}-10^{14} \mathrm{~cm}^{-3}$. The Fe implanted samples, together with non-implanted FZ-Si control wafers, were RCA cleaned and loaded into a furnace at $700{ }^{\circ} \mathrm{C}$, ramped up in dry oxygen at $10^{\circ} \mathrm{C} / \mathrm{min}$, annealed at $1000^{\circ} \mathrm{C}$ in dry oxygen for $1.5 \mathrm{~h}$, followed by $0.5 \mathrm{~h}$ in nitrogen, before being cooled down in nitrogen at a rate of $10^{\circ} \mathrm{C} / \mathrm{min}$, and unloaded at $800^{\circ} \mathrm{C}$. After unloading, the wafers were left to cool in a high airflow and reached room temperature within minutes. The $1000^{\circ} \mathrm{C}$ distribution anneal also resulted in thermally grown silicon dioxide $\left(\mathrm{SiO}_{2}\right)$ layers around $110 \mathrm{~nm}$ thick on the wafer surfaces, which not only acted as diffusion barriers for any possible furnace contaminants but also provided sufficient surface passivation for samples which were set aside as the silicon dioxide $\left(\mathrm{SiO}_{2}\right)$ controls.

A sub-set of the samples had the $\mathrm{SiO}_{2}$ layers removed in a dilute $\mathrm{HF}(1 \%)$ solution and then received a chemical etch in a $\mathrm{HNO}_{3}: \mathrm{HF}(10: 1)$ solution, which further reduced the wafer thicknesses from $180 \mu \mathrm{m}$ to $160-165 \mu \mathrm{m}$ and from $270 \mu \mathrm{m}$ to 260-265 $\mu \mathrm{m}$. These wafers were then coated with plasmaassisted (PA) ALD $\mathrm{Al}_{2} \mathrm{O}_{3}$ films on both sides, using a Beneq TFS-200 ALD system, at a deposition temperature of $175^{\circ} \mathrm{C}$, with a deposition rate of around $0.1 \mathrm{~nm} /$ cycle. Films of 20, 40, and $80 \mathrm{~nm}$ thick were deposited. Trimethylaluminum (TMA) was used as the precursor in ALD, and PA-ALD used as an oxygen plasma as the oxidant. 
To assess the $\mathrm{Fe}_{i}$ loss kinetics in the silicon bulk, both the ALD $\mathrm{Al}_{2} \mathrm{O}_{3}$ and thermally grown $\mathrm{SiO}_{2}$ coated Fe-implanted samples were annealed on a hotplate in air for cumulative times at $425^{\circ} \mathrm{C}$. Non-implanted FZ-Si wafers with either $\mathrm{SiO}_{2}$ or $\mathrm{Al}_{2} \mathrm{O}_{3}$ coatings, which were co-processed in the proceeding steps, were co-annealed at $425^{\circ} \mathrm{C}$ to monitor any changes in surface passivation. The Fe-implanted wafers were pseudosquares of $4 \mathrm{~cm} \times 4 \mathrm{~cm}$, and the co-processed controls were quarters of $10-\mathrm{cm}$ diameter circular wafers. After each cumulative anneal step, a WCT-120 tool from Sinton Instruments ${ }^{14}$ was used to measure the effective minority carrier lifetime of the samples. The interstitial Fe concentration $\left(\left[\mathrm{Fe}_{i}\right]\right)$ in the silicon bulk was determined from lifetimes measured in the isolated $\mathrm{Fe}_{i}$ and $\mathrm{FeB}$ pair states, ${ }^{9,10}$ with strong illumination used to dissociate the FeB pairs. ${ }^{15}$ A photographic flasher provided strong white light with a peak intensity of several hundred suns and a flash time of $1 / 300 \mathrm{~s}$. The flashes were repeated 20-30 times until lifetime saturation, ensuring a full dissociation of the FeB pairs.

The redistribution of $\mathrm{Fe}$ after annealing was measured by SIMS depth profiling of the $\mathrm{Fe}$ concentration in the annealed $\mathrm{Al}_{2} \mathrm{O}_{3}$ or $\mathrm{SiO}_{2}$ layer and the underlying $\mathrm{Si}$ substrate. SIMS measurements were conducted at EAG Laboratories. The nominal depth resolution was better than $1.5 \mathrm{~nm} / \mathrm{step}$ although the actual resolution was limited by the mixing of bombarded ions during SIMS measurements. Silicon and aluminium were monitored as marker species with the secondary ion intensity qualitatively measured, which served to distinguish the locations of the $\mathrm{Al}_{2} \mathrm{O}_{3}$ or $\mathrm{SiO}_{2}$ surface layers, and the $\mathrm{Si}$ wafer bulk, in the depth profiles. Descriptions of the samples for SIMS measurements are given in Table I.

The last two samples in Table I were processed in our previous work, where most of the experimental details can be found. ${ }^{7}$ These 20 -nm thick $\mathrm{SiO}_{2}$ layers were grown from annealing wafers at $900^{\circ} \mathrm{C}$ for $1 \mathrm{~h}$ in dry oxygen, followed by $1 \mathrm{~h}$ in nitrogen, before being cooled in nitrogen at a rate of $10^{\circ} \mathrm{C} / \mathrm{min}$ and unloaded at $750^{\circ} \mathrm{C}$. The SIMS results for these two samples were not shown in Ref. 7.

Note that an $80-\mathrm{nm}$ thick $\mathrm{ALD} \mathrm{Al}_{2} \mathrm{O}_{3}$ film is not typically used in silicon solar cells. This thickness was chosen here because SIMS analysis is prone to measurement artefact extending tens of nanometres from the wafer surfaces, which gives an apparent increase in the Fe concentration towards the surfaces. To ensure that the SIMS measurements of the

TABLE I. Samples for SIMS analysis.

\begin{tabular}{lcc}
\hline \hline Surface layers & Initial bulk $\left[\mathrm{Fe}_{\mathrm{i}}\right]$ & $\begin{array}{c}\text { Annealing temperature } \\
\text { and time }\end{array}$ \\
\hline $\mathrm{ALD} \mathrm{Al}_{2} \mathrm{O}_{3} 80 \mathrm{~nm}$ & $10^{14} \mathrm{~cm}^{-3}$ & $\begin{array}{c}425^{\circ} \mathrm{C}, 1.8 \mathrm{~h} \\
(\text { short anneal })\end{array}$ \\
$\mathrm{ALD} \mathrm{Al}_{2} \mathrm{O}_{3} 80 \mathrm{~nm}$ & $10^{14} \mathrm{~cm}^{-3}$ & $\begin{array}{c}425^{\circ} \mathrm{C}, 18 \mathrm{~h} \\
(\text { long anneal })\end{array}$ \\
$\mathrm{ALD} \mathrm{Al}_{2} \mathrm{O}_{3} 80 \mathrm{~nm}$ & $3 \times 10^{12} \mathrm{~cm}^{-3}$ & $425^{\circ} \mathrm{C}, 18 \mathrm{~h}$ \\
$\mathrm{ALD} \mathrm{Al}_{2} \mathrm{O}_{3} 80 \mathrm{~nm}$ & $\mathrm{Nil}-\mathrm{No}$ & $425^{\circ} \mathrm{C}, 18 \mathrm{~h}$ \\
& $\mathrm{Fe}$ implantation & \\
Thermally grown $\mathrm{SiO}_{2} 110 \mathrm{~nm}$ & $10^{13} \mathrm{~cm}^{-3}$ & $425^{\circ} \mathrm{C}, 18 \mathrm{~h}$ \\
Thermally grown $\mathrm{SiO}_{2} 20 \mathrm{~nm}$ & $10^{13} \mathrm{~cm}^{-3}$ & $700^{\circ} \mathrm{C}, 0.5 \mathrm{~h}$ \\
Thermally grown $\mathrm{SiO}_{2} 20 \mathrm{~nm}$ & Nil $-\mathrm{No}$ & $700^{\circ} \mathrm{C}, 0.5 \mathrm{~h}$ \\
& $\mathrm{Fe} \mathrm{implantation}$ \\
\hline \hline
\end{tabular}

80-nm $\mathrm{Al}_{2} \mathrm{O}_{3}$ samples are representative of the gettering behaviours of typical $\mathrm{ALD} \mathrm{Al}_{2} \mathrm{O}_{3}$ films (commonly less than $30 \mathrm{~nm}$ ), the $\mathrm{Fe}_{i}$ loss kinetics of samples coated with $\mathrm{Al}_{2} \mathrm{O}_{3}$ films of different thicknesses were measured and compared, as shown in Fig. 1.

The effective lifetime measured on non-implanted FZ-Si control samples was largely limited by surface recombination and was found to be always 1-3 orders of magnitude higher than the lifetime of the Fe-contaminated samples, indicating the dominance of bulk lifetime. The lifetime of the control samples was also found to be stable under the strong illumination used to break $\mathrm{FeB}$ pairs for $\left[\mathrm{Fe}_{i}\right]$ measurements. The extraction of $\left[\mathrm{Fe}_{i}\right]$ from effective lifetime measurements was therefore not affected by the changes in surface passivation during illumination or during annealing.

As shown in Fig. 1, the $\mathrm{ALD} \mathrm{Al}_{2} \mathrm{O}_{3}$ and the thermal $\mathrm{SiO}_{2}$ samples display very different $\mathrm{Fe}_{i}$ loss kinetics. The $\mathrm{Al}_{2} \mathrm{O}_{3}$ samples, despite different film thicknesses and initial $\mathrm{Fe}_{i}$ concentrations, all show an initial fast $\mathrm{Fe}_{i}$ loss, which can be fitted by a diffusion-limited surface gettering model with apparent Fe diffusivities of $7 \times 10^{-9} \mathrm{~cm}^{2} / \mathrm{s}$ and $5 \times 10^{-9} \mathrm{~cm}^{2} / \mathrm{s}$. This model takes into account the wafer thickness and simulates the changes in the bulk impurity concentration for impurities that diffuse into the gettering sites on both sides of the wafer surfaces, with a fitted apparent impurity diffusivity. ${ }^{16}$ Although the experimental data for the $3 \times 10^{12} \mathrm{~cm}^{-3}$ sample demonstrate a much slower decline in $\left[\mathrm{Fe}_{i}\right]$ compared to the rest of the $\mathrm{Al}_{2} \mathrm{O}_{3}$ samples, the measured kinetics can be fitted

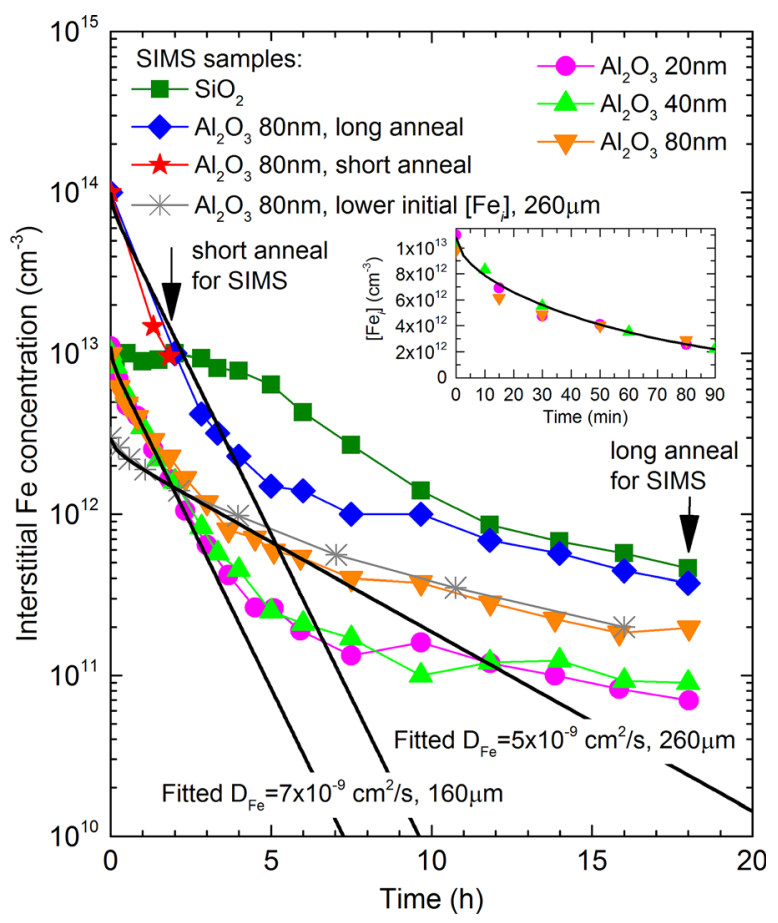

FIG. 1. $\mathrm{Fe}_{i}$ loss kinetics in Fe-contaminated silicon wafers coated with ALD $\mathrm{Al}_{2} \mathrm{O}_{3}$ films of different thicknesses, or with thermally grown $\mathrm{SiO}_{2}$ layers, cumulatively annealed at $425^{\circ} \mathrm{C}$. The straight lines are fits to the experimental data using a diffusion-limited surface-loss model, yielding fitted apparent Fe diffusivities. ${ }^{16}$ Lines connecting the symbols are guides to the eye. The inset shows the $\mathrm{Fe}_{i}$ kinetics during the initial short anneals, for the $\mathrm{Al}_{2} \mathrm{O}_{3}$ samples with an initial $\left[\mathrm{Fe}_{i}\right]$ of $10^{13} \mathrm{~cm}^{-3}$. Note that $\left[\mathrm{Fe}_{i}\right]$ in the inset is plotted on a linear scale instead of a logarithmic scale, and time is in the unit of minutes instead of hours. The SIMS samples have the corresponding SIMS data shown in Figs. $2\left(\mathrm{Al}_{2} \mathrm{O}_{3}\right.$ samples) and $3\left(\mathrm{SiO}_{2}\right.$ sample). 
by a similar apparent $\mathrm{Fe}$ diffusivity, indicating that the slower $\left[\mathrm{Fe}_{i}\right]$ reduction is largely caused by different wafer thicknesses. The reported $\mathrm{Fe}$ diffusivity in the literature is $1.5 \times 10^{-8}$ $\mathrm{cm}^{2} / \mathrm{s}$ at $425^{\circ} \mathrm{C},{ }^{13}$ which is close to the fitted apparent $\mathrm{Fe}$ diffusivities in Fig. 1, suggesting that this fast initial $\mathrm{Fe}_{i}$ loss stage can be considered as representing the diffusion-limited loss of interstitial iron to the surfaces.

The inset in Fig. 1 shows a plot of the fast $\mathrm{Fe}_{i}$ loss kinetics, on a time scale that is relevant for the activation of ALD $\mathrm{Al}_{2} \mathrm{O}_{3}$ films. As shown in the inset of Fig. 1, for a typical $160-\mu \mathrm{m}$ wafer, a 10 -min anneal at $425^{\circ} \mathrm{C}$ reduces $20 \%$ of the bulk $\mathrm{Fe}_{i}$ concentration, and a 30-min anneal reduces the $\mathrm{Fe}_{i}$ concentration by half. Iron has a moderate diffusivity in silicon. This reported gettering effect should be taken into

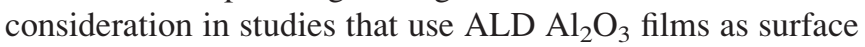
passivation coatings, to avoid misinterpretation.

The initial fast $\mathrm{Fe}_{i}$ reduction stage of the $\mathrm{Al}_{2} \mathrm{O}_{3}$ samples is then followed by a slow-down of the rate of $\mathrm{Fe}_{i}$ loss, with the thicker 80-nm films demonstrating an earlier onset of the slow-down. It is worth mentioning that we also measured the $\mathrm{Fe}_{i}$ loss kinetics in thermal $\mathrm{H}_{2} \mathrm{O}$-based ALD $\mathrm{Al}_{2} \mathrm{O}_{3}$ coated silicon wafers, which were deposited using the same ALD system at $200^{\circ} \mathrm{C}$, and similar, reproducible $\mathrm{Fe}_{i}$ loss kinetics were observed.

The $\mathrm{SiO}_{2}$ coated sample, on the other hand, first shows little change in the $\mathrm{Fe}_{i}$ concentration. With increasing annealing time, however, the $\left[\mathrm{Fe}_{i}\right]$ reduction is initiated and then accelerates, with the onset occurring after $3-5 \mathrm{~h}$. For longer times, both the $\mathrm{SiO}_{2}$ and $\mathrm{Al}_{2} \mathrm{O}_{3}$ samples show a similar rate of $\mathrm{Fe}_{i}$ loss.

To understand the observed gettering effects in Fig. 1, SIMS analysis was performed on the cumulatively annealed $\mathrm{Al}_{2} \mathrm{O}_{3}$ (Fig. 2) and $\mathrm{SiO}_{2}$ (Fig. 3) samples to reveal Fe redistribution. SIMS detects the total Fe concentration regardless of the electrical state, i.e., it detects both dissolved and precipitated Fe. Note that all the SIMS Fe profiles in Figs. 2 and 3, as well as in our previous work, ${ }^{7}$ demonstrate a nearsurface $\mathrm{Fe}$ increase, for samples with different coatings and with or without previous bulk Fe contamination. This suggests that the near-surface $\mathrm{Fe}$ increase does not arise from the gettering of Fe from the silicon bulk and is likely a measurement artefact in SIMS analysis, possibly caused by unintentional surface contamination during handling. Moreover, the diffusion length of $\mathrm{Fe}$ in thermal $\mathrm{SiO}_{2}$ during a $425^{\circ} \mathrm{C}$ 18-h anneal, from extrapolating the diffusivity data, ${ }^{17}$ is estimated to be less than $2 \mathrm{~nm}$, which shows the unlikelihood of Fe to diffuse through an 110 -nm thick $\mathrm{SiO}_{2}$ layer to reach the surface.

Figure 2 shows that, for samples previously contaminated with $\mathrm{Fe}_{i}$ in the silicon bulk, high $\mathrm{Fe}$ concentration peaks are observed at the $\mathrm{Al}_{2} \mathrm{O}_{3} / \mathrm{Si}$ interfaces, with higher initial bulk $\left[\mathrm{Fe}_{i}\right]$ demonstrating higher Fe peaks. The shifts in the peak position along the depth profiles (i.e., x-axis) originate from the slight variations in the deposited film thicknesses, as reflected by the qualitative measurements of the $\mathrm{Si}$ and $\mathrm{Al}$ matrixes (upper curves in Fig. 2). On the other hand, the $\mathrm{Al}_{2} \mathrm{O}_{3}$ control sample without prior bulk $\mathrm{Fe}_{i}$ contamination displays no such $\mathrm{Fe}$ peak, which clearly indicates that the observed $\mathrm{Fe}$ peaks at the $\mathrm{Al}_{2} \mathrm{O}_{3} / \mathrm{Si}$ interfaces arise from $\mathrm{Fe}_{i}$ previously distributed in the silicon wafer bulk; in

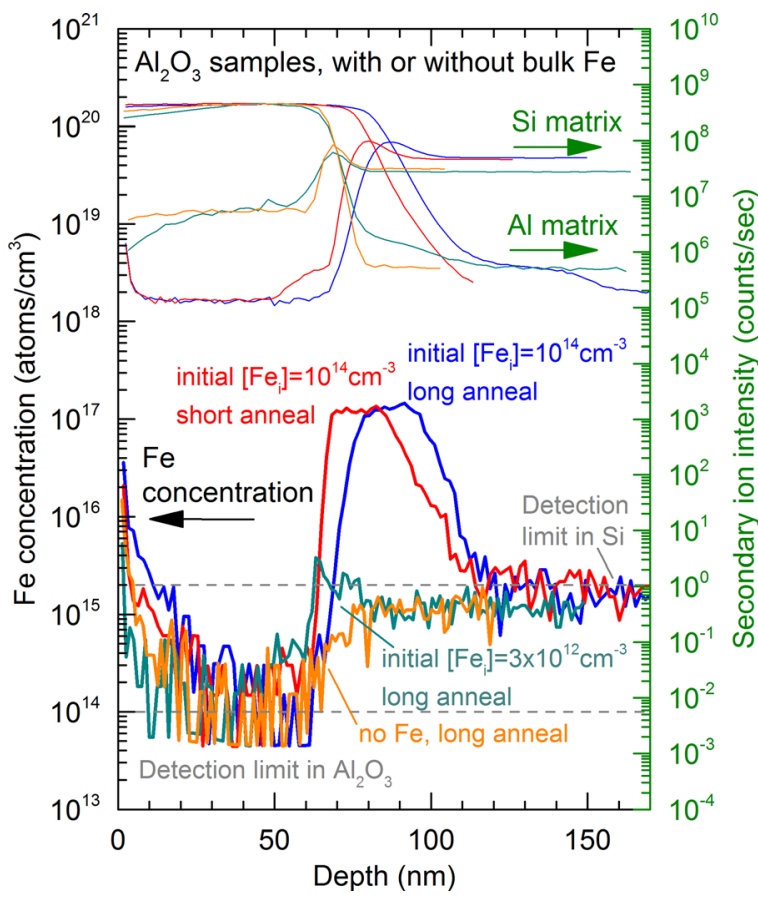

FIG. 2. SIMS profiles of the $\mathrm{Fe}$ distribution in $\mathrm{ALD} \mathrm{Al}_{2} \mathrm{O}_{3}$ coated silicon wafers cumulatively annealed at $425^{\circ} \mathrm{C}$. The samples had different initial bulk Fe concentrations and were annealed for either short $(1.8 \mathrm{~h})$ or long (18h) time durations. The upper curves are a qualitative measure of the $\mathrm{Al}$ and $\mathrm{Si}$ matrixes (plotted against the $\mathrm{y}$-axis on the right), which are used to indicate the positions of the $\mathrm{Al}_{2} \mathrm{O}_{3}$ films and the Si bulk in the depth profiles. The detection limits of $\mathrm{Fe}$ in $\mathrm{Al}_{2} \mathrm{O}_{3}$ and in $\mathrm{Si}$ are marked by dashed lines.

other words, $\mathrm{Fe}_{i}$ is gettered from the silicon bulk to the $\mathrm{Al}_{2} \mathrm{O}_{3} / \mathrm{Si}$ interface. Quantitatively, for samples initially contaminated with $10^{14} \mathrm{~cm}^{-3}$ bulk $\left[\mathrm{Fe}_{i}\right]$ and with the same $\mathrm{Al}_{2} \mathrm{O}_{3}$ films deposited on both sides of the wafer surfaces, the integrated SIMS Fe concentration in these interface peaks is about half of the known implanted $\mathrm{Fe}$ dose. Given that the ion yield from $\mathrm{Al}_{2} \mathrm{O}_{3}$ may depend on the film deposition

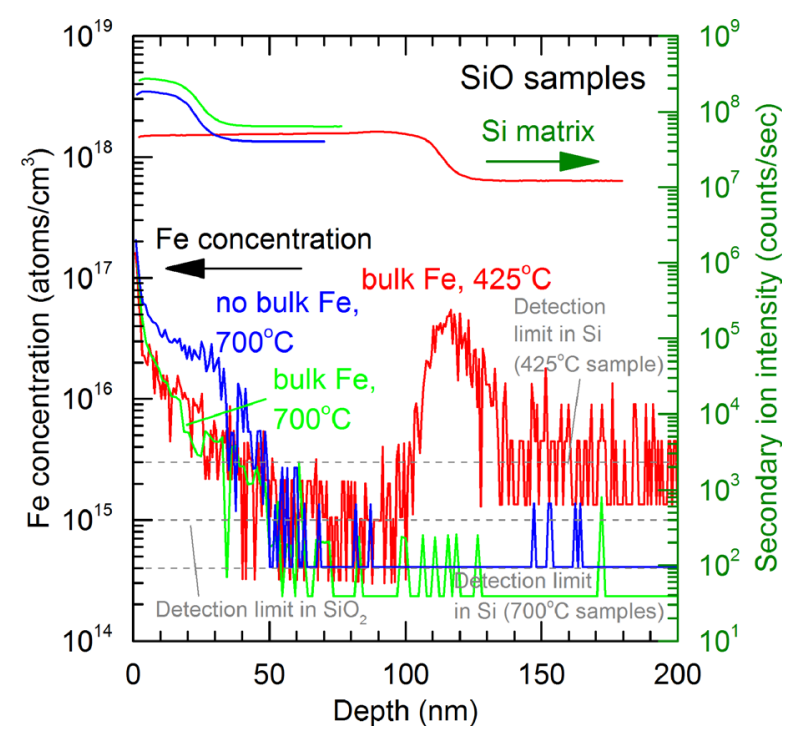

FIG. 3. SIMS profiles of the Fe distribution in thermally grown $\mathrm{SiO}_{2}$ coated silicon wafers, annealed at either $425^{\circ} \mathrm{C}$ for a total of $18 \mathrm{~h}$, with an initial bulk $\left[\mathrm{Fe}_{i}\right]$ of $10^{13} \mathrm{~cm}^{-3}$, or annealed at $700^{\circ} \mathrm{C}$ for $30 \mathrm{~min}$, with or without previous $10^{13} \mathrm{~cm}^{-3}$ bulk $\mathrm{Fe}_{i}$. The top curves are used to indicate the position of the $\mathrm{SiO}_{2}$ layer and the $\mathrm{Si}$ bulk in the depth profiles. The detection limits of $\mathrm{Fe}$ in $\mathrm{SiO}_{2}$ and in $\mathrm{Si}$ are marked by dashed lines. 
conditions, this discrepancy in the Fe concentration is considered reasonable and confirms that the Fe peaks in SIMS profiles originate from the implanted $\mathrm{Fe}$ previously distributed in the silicon bulk.

The accumulation of $\mathrm{Fe}$ at the $\mathrm{SiO}_{2} / \mathrm{Si}$ interface is observed for the Fe-contaminated $\mathrm{SiO}_{2}$ sample annealed at $425^{\circ} \mathrm{C}$, as shown in Fig. 3. The quantitative Fe concentration of this interface peak is again found to be about half of the known implanted $\mathrm{Fe}$ dose, showing general agreement with the reduced $\left[\mathrm{Fe}_{i}\right]$ in the silicon wafer bulk measured by QSSPC. The $700^{\circ} \mathrm{C}$ 30-min annealed Fe-contaminated $\mathrm{SiO}_{2}$ sample, however, shows little change in bulk $\left[\mathrm{Fe}_{i}\right]$ from QSSPC measurements, consistent with previous results, ${ }^{7}$ and the sample also demonstrates no $\mathrm{Fe}$ peak at the $\mathrm{SiO}_{2} / \mathrm{Si}$ interface. The solubility of $\mathrm{Fe}$ at $425^{\circ} \mathrm{C}$ is in the range of $10^{5} \mathrm{~cm}^{-3}$ (Ref. 13) to $10^{8} \mathrm{~cm}^{-3}$ (from extrapolation ${ }^{18}$ ), and the solubility at $700^{\circ} \mathrm{C}$ is $(1-6) \times 10^{11} \mathrm{~cm}^{-3} \cdot{ }^{13,18}$ It is well known that $\mathrm{Fe}$-silicide precipitates tend to form at the $\mathrm{SiO}_{2} /$ $\mathrm{Si}$ interfaces (see, for example, Ref. 11 for a review). The observed $\mathrm{Fe}$ peak at the $\mathrm{SiO}_{2} / \mathrm{Si}$ interface for the $425^{\circ} \mathrm{C} 18$-h annealed sample is therefore likely due to $\mathrm{Fe}$ precipitation. The lack of Fe precipitates for the $700^{\circ} \mathrm{C} 30$-min annealed sample may relate to the short annealing time, as Fig. 1 shows that the onset of $\mathrm{Fe}_{i}$ reduction for $\mathrm{SiO}_{2}$ coated $\mathrm{FZ}-\mathrm{Si}$ wafers requires some time.

$\mathrm{Fe}$ precipitation at the $\mathrm{SiO}_{2} / \mathrm{Si}$ interface could well explain the observed $\mathrm{Fe}_{i}$ loss kinetics for the $\mathrm{SiO}_{2}$ sample shown in Fig. 1. The thermal $\mathrm{SiO}_{2} / \mathrm{Si}$ interface may require a certain nucleation time for the formation of precipitation sites, and hence, the $\mathrm{SiO}_{2}$ sample showed little change in $\left[\mathrm{Fe}_{i}\right]$ in the early stages. These developing precipitation sites later facilitate $\mathrm{Fe}$ precipitation, and therefore, a faster $\left[\mathrm{Fe}_{i}\right]$ loss is observed for the $\mathrm{SiO}_{2}$ sample in later stages.

The underlying mechanism for the observed Fe peaks at the $\mathrm{Al}_{2} \mathrm{O}_{3} / \mathrm{Si}$ interfaces (Fig. 2), however, remains unknown at this stage. As a thin silicon oxide $\left(\mathrm{SiO}_{\mathrm{x}}\right)$ layer is known to reside at the $\mathrm{ALD} \mathrm{Al}_{2} \mathrm{O}_{3} / \mathrm{Si}$ interface, ${ }^{19}$ this $\mathrm{Fe}$ peak may be caused by $\mathrm{Fe}$ precipitation at the $\mathrm{SiO}_{\mathrm{x}} / \mathrm{Si}$ interface, similar to Fe precipitation at the thermal $\mathrm{SiO}_{2} / \mathrm{Si}$ interface. ${ }^{11}$ However, Fig. 1 shows that the $\mathrm{ALD} \mathrm{Al}_{2} \mathrm{O}_{3}$ and thermal $\mathrm{SiO}_{2}$ samples have very different $\mathrm{Fe}_{i}$ loss kinetics. Hence, $\mathrm{Fe}$ accumulation at the $\mathrm{ALD} \mathrm{Al}_{2} \mathrm{O}_{3} / \mathrm{Si}$ interface could be caused by a different mechanism, for example, by impurity segregation at the $\mathrm{Al}_{2} \mathrm{O}_{3} / \mathrm{Si}$ interface. Further temperature-dependent gettering studies will be required to assess the hypotheses.

The 2-stage $\mathrm{Fe}_{i}$ loss kinetics of the $\mathrm{Al}_{2} \mathrm{O}_{3}$ samples (Fig. 1) is investigated by conducting SIMS analysis on samples undergoing either short $(1.8 \mathrm{~h})$ or long $(18 \mathrm{~h})$ anneals (Fig. 2). As shown in Fig. 1, the short anneal sample was still in the initial fast $\mathrm{Fe}_{i}$ loss stage, whereas the long anneal sample had experienced both fast and slow $\mathrm{Fe}_{i}$ reductions. The remaining $10^{13} \mathrm{~cm}^{-3} \mathrm{Fe}_{i}$ gettered by the long anneal sample, if gettered to the 80-nm $\mathrm{Al}_{2} \mathrm{O}_{3}$ film, would demonstrate an Fe concentration of $10^{16} \mathrm{~cm}^{-3}$ distributed in the film, similar to the SIMS Fe profiles of PECVD $\mathrm{SiN}_{\mathrm{x}}$ samples. ${ }^{7}$ If the remaining $10^{13} \mathrm{~cm}^{-3} \mathrm{Fe}_{i}$ were gettered to the $\mathrm{Al}_{2} \mathrm{O}_{3} / \mathrm{Si}$ interface, where Fe peaks are shown be $\sim 20 \mathrm{~nm}$ wide, the long anneal sample would demonstrate a $4 \times 10^{16} \mathrm{~cm}^{-3}$ increase in the peak height, which would be hardly discernible from the existing Fe peak from a short anneal (Fig. 2). The SIMS results in Fig. 2 show that the initial fast $\mathrm{Fe}_{i}$ loss is caused by $\mathrm{Fe}$ accumulation at the $\mathrm{Al}_{2} \mathrm{O}_{3} / \mathrm{Si}$ interface, and the second slow reduction stage is not due to $\mathrm{Fe}$ segregation into the $\mathrm{Al}_{2} \mathrm{O}_{3}$ film. The slow reduction may arise from $\mathrm{Fe}$ accumulation at the $\mathrm{Al}_{2} \mathrm{O}_{3} / \mathrm{Si}$ interface or $\mathrm{Fe}$ gettering by bulk defects within the FZ-Si wafers. As shown in Fig. 1, the onset of the slow reduction stage seems to relate to the film thickness, which may depend on the film properties. ${ }^{19}$ Further studies are needed to understand this correlation.

It is interesting to note that although both ALD $\mathrm{Al}_{2} \mathrm{O}_{3}$ and PECVD $\mathrm{SiN}_{\mathrm{x}}$ films display similar diffusion-limited gettering kinetics at around $400^{\circ} \mathrm{C}, \mathrm{ALD}_{2} \mathrm{Al}_{3}$ films rely on the $\mathrm{Al}_{2} \mathrm{O}_{3} / \mathrm{Si}$ interfaces to achieve impurity accumulation, while PECVD $\mathrm{SiN}_{\mathrm{x}}$ films relocate the impurities into the bulk of the films themselves. ${ }^{7}$

The reported gettering effect of $\mathrm{ALD} \mathrm{Al}_{2} \mathrm{O}_{3}$ films is beneficial for improving the bulk silicon material quality, which can be conveniently coupled with the necessary passivation activation anneal. Further temperature-dependent gettering studies, combined with a close monitoring of the surface passivation quality, will be useful for assessing the overall effect of annealing at different temperatures and times. The potential impact of impurity accumulation on device performance, for example, in terms of shunting, requires further investigations.

In summary, this letter presents experimental evidence for the gettering effect of $\mathrm{ALD} \mathrm{Al}_{2} \mathrm{O}_{3}$ films at a typical film activation temperature of $425^{\circ} \mathrm{C}$, by examining the concentration and re-distribution of iron in silicon. The gettering process is found to be largely diffusion-limited in the early stages, meaning that during a typical $30-\min 425^{\circ} \mathrm{C}$ passivation activation anneal, the dissolved $\mathrm{Fe}$ in a $160-\mu \mathrm{m}$ thick silicon wafer is reduced by half. The gettering effect is shown to be caused by the aggregation of iron at the ALD $\mathrm{Al}_{2} \mathrm{O}_{3} / \mathrm{Si}$ interface.

This work was supported by the Australian Renewable Energy Agency (ARENA) through Project No. RND009. We acknowledge access to NCRIS facilities (ANFF and the Heavy Ion Accelerator Capability) at the Australian National University.

${ }^{1}$ B. Hoex, J. Schmidt, R. Bock, P. P. Altermatt, M. C. M. van de Sanden, and W. M. M. Kessels, "Excellent passivation of highly doped p-type Si surfaces by the negative-charge-dielectric $\mathrm{Al}_{2} \mathrm{O}_{3}$," Appl. Phys. Lett. 91, 112107 (2007).

${ }^{2}$ B. Hoex, J. J. H. Gielis, M. C. M. van de Sanden, and W. M. M. Kessels, "On the c-Si surface passivation mechanism by the negative-chargedielectric $\mathrm{Al}_{2} \mathrm{O}_{3}$," J. Appl. Phys. 104, 113703 (2008).

${ }^{3}$ W. Liang, K. J. Weber, D. Suh, S. P. Phang, J. Yu, A. K. McAuley et al., "Surface passivation of boron-diffused p-type silicon surfaces with $\left(\begin{array}{lll}1 & 0 & 0\end{array}\right)$

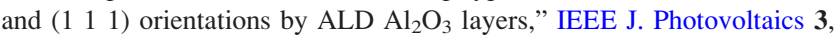
678-683 (2013).

${ }^{4}$ G. Dingemans and W. M. M. Kessels, "Status and prospects of $\mathrm{Al}_{2} \mathrm{O}_{3}$ based surface passivation schemes for silicon solar cells," J. Vac. Sci. Technol., A 30, 040802 (2012).

${ }^{5}$ A. Richter, S. Henneck, J. Benick, M. Hörteis, M. Hermle, and S. Glunz, "Firing stable $\mathrm{Al}_{2} \mathrm{O}_{3} / \mathrm{SiN}_{\mathrm{x}}$ layer stack passivation for the front side boron emitter of n-type silicon solar cells," in Proceedings of the 25th European Photovoltaic Solar Energy Conference and Exhibition (2010), pp. 1453-1456.

${ }^{6}$ S. Gatz, H. Hannebauer, R. Hesse, F. Werner, A. Schmidt, T. Dullweber et al., "19.4\%-efficient large-area fully screen-printed silicon solar cells," Phys. Status Solidi RRL 5, 147-149 (2011). 
${ }^{7}$ A. Y. Liu, C. Sun, V. P. Markevich, A. R. Peaker, J. D. Murphy, and D. Macdonald, "Gettering of interstitial iron in silicon by plasma-enhanced chemical vapour deposited silicon nitride films," J. Appl. Phys. 120, 193103 (2016).

${ }^{8}$ G. Dingemans, F. Einsele, W. Beyer, M. C. M. van de Sanden, and W. M. M. Kessels, "Influence of annealing and $\mathrm{Al}_{2} \mathrm{O}_{3}$ properties on the hydrogen-induced passivation of the $\mathrm{Si} / \mathrm{SiO}_{2}$ interface," J. Appl. Phys. 111, 093713 (2012)

${ }^{9} \mathrm{G}$. Zoth and W. Bergholz, "A fast, preparation-free method to detect iron in silicon,” J. Appl. Phys. 67, 6764-6771 (1990).

${ }^{10}$ D. H. Macdonald, L. J. Geerligs, and A. Azzizi, "Iron detection in crystalline silicon by carrier lifetime measurements for arbitrary injection and doping," J. Appl. Phys. 95, 1021-1028 (2004).

${ }^{11}$ A. A. Istratov, H. Hieslmair, and E. R. Weber, "Iron contamination in silicon technology,” Appl. Phys. A 70, 489-534 (2000).

${ }^{12}$ D. Macdonald, P. N. K. Deenapanray, and S. Diez, "Onset of implantrelated recombination in self-ion implanted and annealed crystalline silicon,” J. Appl. Phys. 96, 3687-3691 (2004).
${ }^{13}$ A. A. Istratov, H. Hieslmair, and E. R. Weber, "Iron and its complexes in silicon," Appl. Phys. A 69, 13-44 (1999).

${ }^{14}$ R. A. Sinton and A. Cuevas, "Contactless determination of current-voltage characteristics and minority-carrier lifetimes in semiconductors from quasi-steady-state photoconductance data," Appl. Phys. Lett. 69, 2510-2512 (1996)

${ }^{15}$ L. Geerligs and D. Macdonald, "Dynamics of light-induced FeB pair dissociation in crystalline silicon," Appl. Phys. Lett. 85, 5227 (2004).

${ }^{16}$ J. D. Murphy and R. J. Falster, "The relaxation behaviour of supersaturated iron in single-crystal silicon at 500 to $750^{\circ} \mathrm{C}$," J. Appl. Phys. 112, 113506 (2012).

${ }^{17}$ D. A. Ramappa and W. B. Henley, "Diffusion of iron in silicon dioxide," J. Electrochem. Soc. 146, 3773-3777 (1999).

${ }^{18}$ J. D. Murphy and R. J. Falster, "Contamination of silicon by iron at temperatures below $800^{\circ}$ C," Phys. Status Solidi RRL 5, 370-372 (2011).

${ }^{19}$ F. Werner, B. Veith, D. Zielke, L. Kühnemund, C. Tegenkamp, M. Seibt et al., "Electronic and chemical properties of the $\mathrm{c}-\mathrm{Si}_{1} / \mathrm{Al}_{2} \mathrm{O}_{3}$ interface," J. Appl. Phys. 109, 113701 (2011). 